\title{
Learning to Love
}




\title{
The Politics of Marriage and Gender: Global Issues in Local Contexts
}

\author{
Series Editor: Péter Berta
}

The Politics of Marriage and Gender: Global Issues in Local Contexts series from Rutgers University Press fills a gap in research by examining the politics of marriage and related practices, ideologies, and interpretations, and addresses the key question of how the politics of marriage has affected social, cultural, and political processes, relations, and boundaries. The series looks at the complex relationships between the politics of marriage and gender, ethnic, national, religious, racial, and class identities, and analyzes how these relationships contribute to the development and management of social and political differences, inequalities, and conflicts.

Joanne Payton, Honor and the Political Economy of Marriage: Violence against

Women in the Kurdistan Region of Iraq

Rama Srinivasan, Courting Desire: Litigating for Love in North India

Hui Liu, Corinne Reczek, and Lindsey Wilkinson, eds., Marriage and Health: The Well-Being of Same-Sex Couples

Sara Smith, Intimate Geopolitics: Love, Territory, and the Future on India's Northern Threshold

Rebecca Joubin, Mediating the Uprising: Narratives of Gender and Marriage in Syrian Television Drama

Raksha Pande, Learning to Love: Arranged Marriages and the British Indian Diaspora 


\section{Learning to Love}

\section{Arranged Marriages and the British Indian Diaspora}

RAKSHA PANDE

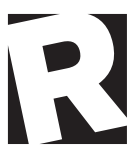

RUTGERS UNIVERSITY PRESS 
Library of Congress Cataloging-in-Publication Data

Names: Pande, Raksha, author.

Title: Learning to love: arranged marriages and the British Indian diaspora / Raksha Pande.

Description: New Brunswick, New Jersey: Rutgers University Press, [202I] |

Series: The politics of marriage and gender: global issues in local contexts |

Includes bibliographical references and index.

Identifiers: LCCN 2020027648 | ISBN 97808I3599632 (paperback) |

ISBN 97808I3599649 (hardcover) | ISBN 97808I3599656 (epub) |

ISBN 97808I3599663 (mobi) | ISBN 97808I3599670 (pdf)

Subjects: LCSH: Arranged marriage-Great Britain. | East Indians-

Marriage customs and rites-Great Britain.

Classification: LCC HQ8O2 .P36 2O2I | DDC 392.5094I-dc23

LC record available at https://lccn.loc.gov/2020027648

A British Cataloging-in-Publication record for this book is available from the British Library.

Copyright (c) 202I by Raksha Pande

All rights reserved

No part of this book may be reproduced or utilized in any form or by any means, electronic or mechanical, or by any information storage and retrieval system, without written permission from the publisher. Please contact Rutgers University Press, I06 Somerset Street, New Brunswick, NJ 0890I. The only exception to this prohibition is "fair use" as defined by U.S. copyright law.

@ The paper used in this publication meets the requirements of the American National Standard for Information Sciences-Permanence of Paper for Printed Library Materials, ANSI Z39.48-I992.

www.rutgersuniversitypress.org

Manufactured in the United States of America 
For my parents and their Pandemonium 
